\title{
Study the Physico-Chemical Properties of Sapota (Achras Sapota L.)
}

\author{
SS Jadhav, Shrikant Baslingappa Swami* and KH Pujari \\ Department of Post Harvest Engineering, Post Graduate Institute of Post Harvest Management, Killa-Roha, 402116 Dist Raigad, Maharashtra State, \\ India
}

Submission: July 24, 2018; Published: October 05, 2018

*Corresponding author: Shrikant Baslingappa Swami, Department of Post Harvest Engineering, Post Graduate Institute of Post Harvest Management, Killa-Roha, India, Email: swami_shrikant1975@yahoo.co.in

Abstract

In the present work, the physical and chemical properties of fresh sapota fruits (Achras sapota $L$ ). And the Physical Properties studies such as moisture content $(\%)$, length $(\mathrm{mm})$, width $(\mathrm{mm})$, thickness $(\mathrm{mm})$, volume $(\mathrm{cc})$, Sphericity , weight of fruits $(\mathrm{g})$, Bulk density (g/cc), True density (g/cc) and Porosity (g/cc). Chemical properties is TSS ${ }^{\circ}(\mathrm{B})$, Acidity (\%), pH, Reducing sugar (\%), Total Sugar (\%), Protein (\%), Fat (\%), Carbohydrate (\%), Fiber (\%), Color L, a and b.

Moisture content of sapota found to be in the range of $73.07 \%$ wet basis $(280.283 \% \mathrm{db})$, the results showed that The length, width and thickness is sapota fruits was found to vary in the ranges from 44.08 to $60.19,37.00$ to 49.34 and 41.06 to $52.91 \mathrm{~mm}$, respectively, The volume of the sapota fruits range is 20 to $70 \mathrm{~cm}^{3}$, Sphericity of sapota fruits range is found to be 0.842 to 0.990 , average weight of sapota fruits was $52.99 \pm 7$. the weight of sapota fruits are recorded the range 41.15 to 74.99 (g), Sapota fruits are bulk density was in the range of found 0.341 to $0.414 \mathrm{~g} / \mathrm{cc}$, True density of sapota fruits was in the range of found 0.952 to $2.1095 \mathrm{~g} / \mathrm{cc}$, The porosity is calculated by the sapota fruits was found in the range of 16.62 to 42.22 . chemical properties results shows the The fresh sapota fruits the TSS range is found 17 to 23 , Titratable acidity of sapota fruits was in the of range 0.2 to $0.25, \mathrm{pH}$ of sapota fruits range was observed in the range 5.5 to 6.0 , Reducing sugar of fresh sapota fruits range was 15 to 17.3 , Total sugars of fresh sapota are range between 46 to 52.2 .

The fresh Sapota fruit protein is range is 0.6 to 0.80 , The carbohydrate of sapota fresh fruits range is 14.3 to 28.31 . The fat of Sapota fresh fruits range 0.4 to 1.25 , Fibre of sapota was range of 0.42 to 28.31 , Colour L values of fresh sapota fruits are range are 57.70 to 72.10 , Colour a value of sapota fruits are range found 7.10 to 10.42 and b value of colour in sapota fruits are range comes in 37.26 to 41.91 .

Keywords: Sapota fruit, Dimensions, Physical properties, Post-harvest processing.

\section{Introduction}

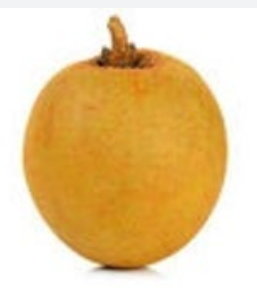

(a)

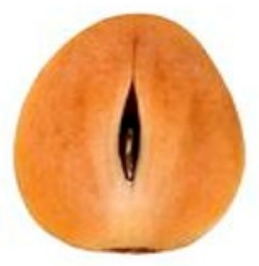

(b)
Figure 1: a) Whole sapota fruit; b) cut sapota fruit
Sapodilla, (Manilkara Zapota L.) which belongs to the family sapotaceae, is underutilized tropical fruits commonly known as "sapota" in India and "chiku" in Malaysia. Immature fruits are hard, gummy and rich in tannin (astringent), while the ripe fruits are soft and juicy, with a sweet taste an attractive range colour, which makes them wonderful dessert fruit [1]. In India it is grown in an area of 82000 ha with 8 tones production at 14.19 tonnes per hectors productivity. Sapota is grown on a commercial basis in India, the Philippines, Srilanka, Malaysia, Mexico, Venezuela, Guatemala and other central American countries [2]. In Maharashtra, Gujarat, Tamilnadu and Karnataka states sapota is grown commercially [3]. Raw fruits of sapota are astringed, while ripe fruits are sweet. It is mainly used as dessert fruits bedside many processed products are prepared from sapota namely Halwa, Juice, Milk Shake, Shrikhand, fruit Jam. Mature fruits are used for making mixed fruits jams and provide a valuable source of raw materials for manufacture of industrial glucose, protein and natural fruits jellies. They also are canned as slices [4]. Sapota is a small fruit, generally with a diameter range from 5 to $9 \mathrm{~cm}$ with round to egg shaped appearance, and 75- $200 \mathrm{~g}$ weight. It consists 
of a rough brown skin, which enclosed a soft, sweet, light brown to reddish brown flesh. The flesh is often gritty, much like a pear, and which holds three to four flat, smooth black seeds, although some fruits are seedless. Figure 1 shows the sapota fruits and cut sapota fruits. Superior strains have a time smooth texture with a slight fragrant and sweet flavour [5].

Sapota fruits is reported to contain sugar, acids, protein, amino acid, phenolics viz, galic acid, catechin, chlorogenic acid, leucodelphinidin, and leucodelargonidin and Leucopelargonidin, carotenoids, ascorbic acids, and minerals like potassium, calcium and iron (Selvaraj and Pal) [6-9]. Fruits contains carbohydrate (50.49 g-100 g), protein $(0.7 \mathrm{~g}-100 \mathrm{~g})$, fat (1.1 g - 100g), fibre (2.6g $-100 \mathrm{~g})$, and minerals nutrient viz. calcium (28mg $-100 \mathrm{~g})$, iron $(2.0 \mathrm{mg}-100 \mathrm{~g})$, phosphorus $(27 \mathrm{mg}-100 \mathrm{~g})$, ascorbic acid (6.0mg -100g), Golpalan et al., Size and shape are most often used when describing grains, seeds, fruits and vegetables. Shapes and physical dimensions are important in sorting and sizing of fruits and determination how many fruits can be placed in shipping containers or plastic bags of a given size. Quality difference in fruits, vegetables, grains and seeds can often be detected by differences in density. When fruits and vegetables are transported hydraulically, the design fluid velocities are related to both density and shape [10]. Quality is defined as the absence of defects or degree of excellence and it includes appearance, color, shape, injuries, flavor, taste, aroma, nutritional value and being safe for the consumer [11]. Due to a higher market exigency as for high quality products, the juice and pulp industries have been looking for fruits with better internal and external features, including fruit length and width; fruit weight; pulp, seed and peel percentages per fruit; number of seeds per fruit; seed size and peel diameter; soluble solids (ํㅜix); Titratable acidity (\%); vitamin C content (mg/100g of fresh fruit); pulp pH and soluble solids/ Titratable acidity ratio. The physical properties affect conveying characteristics of solid materials by air of any sample. Size, shape and physical dimensions of sapota are important in sizing, sorting and other separation processes. Bulk and true densities of sapota are necessary to design the equipment for processing and storing. The porosity of fruits is the most important for packing, $\mathrm{pH}$ is used to determine the acidity and alkalinity of the fruits, and TSS is used to determine the amount of sugar concentration. Many studies have been reported on physical properties of fruits such as Apple, Apricot, Banana, Olive, Pomegranate and grape by the researches [12-17]. The literature on physico-chemical properties of sapota is scarce. The present work was undertaken to study the physico-chemical properties of sapota fruits.

\section{Materials and Methods}

\section{Moisture content}

The moisture content of sapota kalipatti variety fruits was used for the experiments. The moisture content was determined by using a standard hot air oven method [18]. The sapota was cut into slices around 10 to $15 \mathrm{~g}$ and slices were kept in pre weighed moisture boxes by using electronic balance of $300 \mathrm{~g}$ capacity having the least count of $0.001 \mathrm{~g}$. These samples were kept in hot air oven for $105^{\circ} \mathrm{C} \pm 1^{\circ} \mathrm{C}$ for 24 hours. The moisture content (wb\%) was determined as equation (1)

$$
\begin{aligned}
& \text { MoistureContent }(d b \%)=\frac{w_{2}-w_{3}}{w_{2}-w_{1}} \times 100---(1) \\
& \text { Where, } \\
& \mathrm{W}_{1}=\text { mass of empty box with lid, } \mathrm{g} \\
& \mathrm{W}_{2}=\text { mass of box, lid with sample, } \mathrm{g} \\
& \mathrm{W}_{3}=\text { mass of box, lid with sample after } 24 \text { hours, } \mathrm{g}
\end{aligned}
$$

\section{Dimensions (L, B, T)}

The three principal dimensions namely length, width (Diameter) and thickness was measured for each individual sapota along X, Y, and Z axis with the help of Vernier caliper (least count of $0.01 \mathrm{~mm}$ ). The spatial dimensions were measured for 50 fruits and average value has been reported. Geometric mean diameter was calculated by following equation (2)

$D_{g}=[(L \times B \times T)]^{\left(\frac{1}{3}\right)}---(2)$

Where,

$\mathrm{D}_{\mathrm{g}}=$ Geometric Mean Diameter in mm

$\mathrm{L}=$ Length $\mathrm{mm}$

$\mathrm{B}=$ Breadth, $\mathrm{mm}$

$\mathrm{T}=$ Thickness, $\mathrm{mm}$

\section{Sphericity}

It is defined as ratio of surface area of sphere having same volume as that of the sapota to the surface area of the sapota [19]. This criterion was used to describe the shape of the sapota. Sphericity of sapota fruit was determined by using equation (3).

$$
\text { Sphericity }=\frac{(L \times B \times T)^{\frac{1}{3}}}{L}
$$

\section{Fruit weight}

Samples of sapota were taken and their weights were measured on an electronic weighing machine with the $0.001 \mathrm{~kg}$ least count. The maximum, minimum, and average values of these parameters were recorded and standard deviation of the mean values was tabulated.

\section{Fruit volume}

A $1000 \mathrm{ml}$ measuring cylinder was used for measurement of fruit volume. Measuring cylinder was filled with water up to $500 \mathrm{ml}$. the fruit is dropped in the measuring cylinder. The initial volume before placed was recorded for fruit. The volume change after dropping the fruit in to the cylinder was recorded. The measurement was repeated 10 times the change in volume was reported as the volume of fruit. The average of 10 measurement were reported as a fruits volume using equation,

$$
F_{v}=B-A--(4)
$$


Where,

$\mathrm{F}_{\mathrm{v}}=$ fruit volume,

$\mathrm{A}=$ Initial level of water in the measuring cylinder, $\mathrm{ml}$

$\mathrm{B}=$ final level of water in the measuring cylinder, $\mathrm{ml}$

\section{Bulk density}

The bulk density was determined by using the mass/volume relationship. Sapota were filled in gunny bag having volume $(100 \mathrm{~cm} \times 60 \mathrm{~cm} \times 30 \mathrm{~cm})$. Total mass of the sapota were measured with the electronic balance with accuracy of $0.01 \mathrm{~g}$. Fruit density $\left(\mathrm{kg} / \mathrm{m}^{3}\right)$ was calculated by using the following equation (5). The experiments were repeated with five times and average value was reported. The bulk density of sapota fruit was determined by using following formula as suggested by Mohasnin.

$$
\begin{aligned}
& P_{b}=\frac{M}{V}---(5) \\
& \text { Where, } \\
& \mathrm{P}_{\mathrm{b}}=\text { bulk density }\left(\mathrm{kg} / \mathrm{m}^{3}\right), \\
& \mathrm{M}=\text { bulk mass of fruit }(\mathrm{kg}), \text { and } \\
& \mathrm{V}=\text { volume of Gunny bag }(100 \mathrm{~cm} \times 60 \mathrm{~cm} \times 30 \mathrm{~cm}) .
\end{aligned}
$$

\section{True density}

The true density of sapota fruit was determined by using toluene displacement method. Weight of single sapota fruit was taken with electronic precision balance with least count 0.001 $\mathrm{g}$ and fruit was immersed carefully into measuring cylinder partially filled with toluene. The volume of toluene displaced by the fruit was noted down. The true density was calculated by using following equation (6).

$$
\begin{aligned}
& P_{t}=\frac{W}{V_{t d}}---(6) \\
& \text { Where, } \\
& \mathrm{P}_{\mathrm{t}}=\text { True density g/cc, } \\
& \mathrm{V}_{\mathrm{td}}=\text { volume of cylinder content }(\mathrm{cc}) . \\
& \mathrm{W}=\text { Wight of sapota fruits }
\end{aligned}
$$

\section{Porosity}

The porosity of sapota was computed from the value of bulk density and true density using relationship.

$$
\text { Porosity }=\frac{\text { True density }- \text { Bulk density }}{\text { True density }} \times 100^{---(7)}
$$

\section{Total Soluble Solids ${ }^{0}$ (BRIX)}

Total soluble solids sapota pulps were determined using Refractometer (M/s. Atago, Japan) at atmospheric temperature. The equipment was calibrated with distilled water and the TSS of the Sapota juice was determined. The experiment was replicated three times. The total soluble solid content of fruit samples was determined by a digital Refractometer (Kyoto Company, Kyoto, Japan).

\section{Titratable Acidity}

The Titratable acidity of sapota fruit pulp was determined as per the procedure Ranganna. A known quantity of sample was blended in mortar and pestle with $20-25 \mathrm{ml}$ distilled water. It was then transferred to $100 \mathrm{ml}$ volumetric flask, made up the volume and filtered. A known volume of aliquot $(10 \mathrm{ml})$ was titrated against $0.1 \mathrm{~N}$ sodium hydroxide $(\mathrm{NAOH})$ solution using phenolphthalein as an indicator (Ranganna). The acidity was calculated as given below and the results were expressed as percent anhydrous citric acid. The three replications were carried out and the average readings were reported.

$$
\text { Titratable acidity }(\%)=\frac{N \times T \times E}{W \times V \times 1000} \times 10---(8)
$$

Where,

$$
\begin{aligned}
& \mathrm{N}=\text { normality of alkali } \\
& \mathrm{T}=\text { titrate reading } \\
& \mathrm{E}=\text { equivalent mass of acid, } \mathrm{g} \\
& \mathrm{W}=\text { weight of the sample, } \mathrm{g} \\
& \mathrm{V}=\text { total volume of the sample, } \mathrm{g}
\end{aligned}
$$

pH

$\mathrm{pH}$ of sapota was measured using digital $\mathrm{pH}$ meter. The digital $\mathrm{pH}$ meter is firstly calibrated by using $4 \mathrm{pH}$ and $7 \mathrm{pH}$ buffer solution. The electrode was washed with distilled water and blot led with tissue paper. $10 \mathrm{ml}$ of sapota juice was taken in beaker, and then the tip of electrode and temperature probe was then submerged in to the sample. The $\mathrm{pH}$ reading display on the primary LCD and temperature on secondary one. The $\mathrm{pH}$ of fresh sapota was determined for three replications. The chemical properties such as $\mathrm{pH}$ of meddler fruit were determined according to the methods presented by the Association of Official Analytical Chemists.

\section{Reducing Sugar}

The reducing sugar of sapota pulp was estimated by using Lane and Eynon Method with modifications reported by Ranganna. A known weight of Sapota slices were crushed with distilled water using lead acetate $(45 \%)$ for precipitation of extraneous material and potassium oxalate $(22 \%)$ to de-lead the solution. This lead free extract was used to estimate reducing sugars titrating against standard Fehling mixture (Fehling ' $\mathrm{A}$ ' and ' $\mathrm{B}$ ' in equal proportion) using methylene blue as an indicator to brick red end point. The three replication were carried out and the average reading was reported.

$$
\text { Reducing sugar } \%=\frac{100}{\text { burettereading }} \times \frac{\text { volume prepared }}{\text { initial volume }} G \text { V of fehling 's solution -.- (9) }
$$

Where,

$$
\mathrm{GV}=\text { Glucose value }
$$

\section{Total Sugar}

Total sugars of sapota pulp estimated by same procedure of reducing sugar after acid hydrolysis of an aliquot of deleaded 
sample with 50 percent of hydrochloric acid followed by neutralization with sodium hydroxide (40\%) and calculated as below. The experiment was repeated three times to get the replication.

$$
\begin{aligned}
& \text { Total sugar }(\%)=\frac{\text { Factor } \times \text { Dilution }}{\text { Titre reading } \times \text { Weight of sample }} \times 100 \text {---(10) } \\
& \text { Colour }
\end{aligned}
$$

The fresh sapota fruit pulp was used to measure the colour value by using colorimeter (Konica minotta, Japan model-Meter CR-400). The equipment was calibrated against standard white tile. Around $20 \mathrm{~g}$ pulp of sapota was taken in the glass cup; the cup was placed on the aperture of the instrument. The colour was recorded in terms of $\mathrm{L}=$ lightness (100) to darkness (0); $\mathrm{a}=$ Redness $(+60)$ to Greeness $(-60)$; b= yellowness $(+60)$ to blueness $(-60)$.

\section{Protein}

The protein content of fresh sapota fruits was determined by Lowry's Method (Lowry et al.,) using spectrophotometer (Make: Systronics- UV Visible spectrophotometer; Ahmadabad; Model No: 106). In this method, $1 \mathrm{~g}$ sapota pulp was mixed with $5 \mathrm{ml}$ of alkaline solution which was prepared from $50 \mathrm{ml}$ of Part one ( $2 \%$ sodium carbonate in $0.1 \mathrm{~N} \mathrm{NaOH}$ ) solution and $1 \mathrm{ml}$ of part two $(0.5 \%$ copper sulphate in $1 \%$ sodium potassium tartarate) solution. Mixed solution i.e. part one and part two was rapidly diluted with folin-ciocalteu reagent. After $30 \mathrm{~min}$, sample was loaded in the cuvet of spectrophotometer upto $>3 / 4$ of its level. The absorbance was read against standard protein solution at $750 \mathrm{~nm}$. Absorbance is recorded as protein content.

\section{Fat}

Fat of sapota fresh fruit pulp was determined using soxhlet fat extraction system (AOAC) by using Soxhlet apparatus (Make: Elico, Hyderabad). In this method, initially weight of empty flask was weighed. $2 \mathrm{~g}$ sapota pulp wrapped in filter paper was siphoned for 9-12 times with the petroleum ether in soxhlet apparatus. After removing assembly, evaporation of petroleum ether was allowed by heating. Residue remained at the bottom of the flask and was reweighed with flask. The quantity of residue was determined as fat content of sapota pulp.

\section{Carbohydrate}

The carbohydrate from sapota pulp was estimated by anthrone method in which prepared a series of Glucose solution and distilled water in the ratio $(0: 1 ; 0.2: 0.8 ; 0.4: 0.6 ; 0.6: 0.4 ; 0.8: 0.2$; and $1: 0)$ by using spectrophotometer. One gram ground sapota pulp was mixed with $5 \mathrm{ml}$ of $2.5 \mathrm{~N} \mathrm{HCL}$ and then heated for $3 \mathrm{~h}$ in water bath. The mixture was allowed to cool for $1.3 \mathrm{~h}$, and it is added with sodium carbonate till effervescence stops. It is seen by naked eyes. After filtration, anthrone reagent $(2 \mathrm{~g}$ anthrone powder $100 \mathrm{ml}$ $\mathrm{H}_{2} \mathrm{SO}_{4}$ ) was added in filtered solution. The mixture was heated for $8 \mathrm{~min}$ and allowed to cool. The solution was taken in the cuvette of spectrophotometer, and absorbance was recorded at $630 \mathrm{~nm}$. A graph was plotted, i.e., absorbance versus concentration (glucose stock: distilled water), and concentration of unknown sample was measured by using formula,

Concentration $\%=\frac{\text { Absorbance of unknown-Concentration of standard }}{\text { Absorbance of standard }}$

\section{Results and Discussion}

Table 1 shows the physical properties of sapota fruits \& Table 2 shows the chemical properties of sapota fruits.

Table 1: Physical properties of sapota fruits.

\begin{tabular}{|c|c|c|c|}
\hline Properties & Range & Average & $\begin{array}{c}\text { Standard Devi- } \\
\text { ation }\end{array}$ \\
\hline Moisture content \% & $72-78$ & 75.2 & 1.6 \\
\hline Length (mm) & 44.08 to 60.19 & 50.29 & 4.15 \\
\hline Width (mm) & 37 to 49.34 & 42.78 & 3.12 \\
\hline Thickness (mm) & 41.06 to 52.91 & 46.53 & 3.13 \\
\hline Volume (cc) & 20 to 70 & 43.2 & 15.19 \\
\hline Fruit weight (g) & 41.15 to 74.99 & 52.19 & 7.909 \\
\hline Sphericity & 0.842 to 0.990 & 0.908 & 0.052 \\
\hline Bulk density (g/cc) & 0.341 to 0.414 & 0.384 & 0.0321 \\
\hline True density(g/cc) & 0.952 to 2.1095 & 1.323 & 0.4 \\
\hline Porosity(g/cc) & 16.62 to 42.22 & 31.492 & 8.45 \\
\hline
\end{tabular}

Table 2: Chemical properties of fresh sapota fruits.

\begin{tabular}{|c|c|c|c|}
\hline Properties & Range & Average & $\begin{array}{c}\text { Standard devi- } \\
\text { ation }\end{array}$ \\
\hline TSS $^{\circ}(\mathrm{B})$ & $17-23$ & 19.45 & 1.4 \\
\hline Acidity (\%) & $0.2-0.25$ & 0.16 & 0.14 \\
\hline pH & $5.5-6.0$ & 5.72 & 0.14 \\
\hline Reducing sugar (\%) & $15-17.3$ & 16.3 & 1.23 \\
\hline Total Sugar (\%) & $46-52.2$ & 48.5 & 1.58 \\
\hline Colour L & $54.70-72.10$ & 71.1 & 2.43 \\
\hline a & $7.10-10.42$ & 7.14 & 0.02 \\
\hline b & $37.26-41.91$ & 40.5 & 0.03 \\
\hline Protein\% (\%) & $0.6-0.80$ & 0.5 & 0.13 \\
\hline Fat\% (\%) & $0.4-1.25$ & 0.49 & 0.44 \\
\hline Carbohydrate (\%) & $14.3-28.31$ & 19.5 & 3.47 \\
\hline Fibre (\%) & 0.42 & 2.5 & 0.92 \\
\hline
\end{tabular}

\section{Moisture content}

Moisture content of sapota found to be in the range of 73.07 $\%$ wet basis $(280.283 \% \mathrm{db})$. The result was in general agreement with the result obtained for fresh sapota fruits by pawar et al., which having range is $69.80 \%$ to $75.80 \%$ (wb) for kalipatti and Athmaselvi et al., reported the moisture content of sapota verity kalipatti 77.93\% (wb). 


\section{Dimension}

The length, width and thickness is sapota fruits was found to vary in the ranges from 44.08 to $60.19,37.00$ to 49.34 and 41.06 to $52.91 \mathrm{~mm}$, respectively. The Average values of dimension in terms of length, width and thickness were found to be $50.29 \pm 4.15$, $42.78 \pm 3.12$ and $46.53 \pm 3.130 \mathrm{~mm}$, respectively. The shape of sapota fruit may be classified as Eleptical as per classification given by Mohsenin [19]. The result were in general agreement with the result obtained for fresh sapota fruits by Gupta et al., 50.10 to $62.19,31.90$ to 42.16 and 27.40 to 41.42 . And Athmaselvi et al., 41.51, 42.16 and 40.3 .

\section{Fruit volume}

The volume of the sapota fruits range is 20 to $70 \mathrm{~cm}^{3}$ and average volume are found of sapota is $43.2 \pm 15.19 \mathrm{~cm}^{3}$.). The result was in general agreement with the result obtained for fresh sapota fruits by Gupta et al., is 408.3 to 587.7 (cc).

\section{Sphericity}

The Sphericity of sapota fruits range is found to be 0.842 to 0.990 and average value is $0.908 \pm 0.052$.and the shape of sapota fruit may be classified as elliptical as per classification given by Mohsenin [19]. The results were in general agreement with the result obtained for fresh sapota fruits by Athmaselvi et al., is 0.957 .

\section{Fruits weight}

The average weight of sapota fruits was $52.99 \pm 7$.the weight of sapota fruits are recorded the range 41.15 to $74.99(\mathrm{~g})$. The result reported in literature for fresh sapota fruits by Gupta et al., range of 38.20 to 55.50 (g) verities in sapota kalipatti and Athmaselvi et al., was 48.42 kalipatti [20] reported average fruits weight of sapota was 55.6 verities cricket boll (g). And pawar et al., reported the sapota fruits weight range of 60.66 to 85.42 (g) for kalipatti.

\section{Bulk density}

Sapota fruits are bulk density was in the range of found 0.341 to $0.414 \mathrm{~g} / \mathrm{cc}$ and the average value of the bulk density of sapota was $0.384 \pm 0.0321 \mathrm{~g} / \mathrm{cc}$ [21]. The result were in general agreement with the result obtained for fresh sapota fruits by Gupta et al., and Athmaselvi et al., range is 0.891 to $0.912 \mathrm{~g} / \mathrm{cc}, 0.61 \mathrm{~g} / \mathrm{cm}^{3}$.

\section{True density}

True density of sapota fruits was in the range of found 0.952 to $2.1095 \mathrm{~g} / \mathrm{cc}$. and average true density is sapota $1.323 \pm 0.40$ $\mathrm{g} / \mathrm{cc}$ [22]. The result were in general agreement with the result obtained for fresh sapota fruits by Gupta et al., for kalipatti and Athmaselvi et al., range is 1.013 to $1.055 \mathrm{~g} / \mathrm{cc}$ and $1.12 \mathrm{~g} / \mathrm{cm}^{3}$.

\section{Porosity}

The porosity is calculated by the sapota fruits was found in the range of 16.62 to 42.22 and average value of porosity is31.492 \pm 8.45 [23]. The result were in general agreement with the result obtained for fresh sapota fruits by Gupta et al., and Athmaselvi et al., range is 12.82 to 13.62 . And $0.35 \mathrm{~g} / \mathrm{cm}^{3}$.

\section{TSS}

The fresh sapota fruits the TSS range is found 17 to 23 and average value of sapota fruits is $19.45 \pm 1.40$. The result were in general agreement with the result obtained for fresh sapota fruits by Pawar et al., which having range is $19.00^{\circ} \mathrm{B}$ to $23.60^{\circ} \mathrm{B}$ reported TSS of sapota average $24^{\circ} \mathrm{B}$. Gupta et al., reported TSS of sapota average range $17^{\circ} \mathrm{B}$ to $22^{\circ} \mathrm{B}$ [20].

\section{Titratable Acidity}

The Titratable acidity of sapota fruits was in the of range 0.2 to 0.25 , the average Titratable acidity is $0.16 \pm 0.14$. The result were in general agreement with the result obtained for fresh sapota fruits by Pawar et al., which having range is $0.10 \%$ to $0.23 \%$.

pH

The $\mathrm{pH}$ of sapota fruits range was observed in the range 5.5 to 6.0 and average $\mathrm{pH}$ is $5.72 \pm 0.14$. The result were in general agreement with the result obtained for fresh sapota fruits by Pawar et al., which having range is 5.30 to 6.30 . Gupta et al., range 5.2 to 5.7 [24].

\section{Reducing sugar}

Reducing sugar of fresh sapota fruits range was 15 to 17.3, average reducing sugar are $16.3 \pm 1.23$. The reducing sugar reported for fresh sapota fruits by Pawar et al., was in the range of $8.90 \%$ to $11.08 \%$. And Take et al., average $8.91 \%$. Sawant reported the reducing sugar content of sapota at ripe stage was 8.28-13.86\%.

\section{Total sugar}

Total sugars of fresh sapota are range between 46 to 52.2 and average total sugar of fresh sapota fruits $48.50 \pm 1.58$. The result were in general agreement with the result obtained for fresh sapota fruits by Pawar et al., which having range is $14.40 \%$ to $18.20 \%$ verities kalipatti [20] reported average total sugar $17.57 \%$ evaluated ten cultivar of sapota and noticed variation from 7.0 to 12.3 per cent in total sugar [7]. Rao et al., observed that in sapota fruit contained 12.0 per cent total sugar.

\section{Protein}

The fresh Sapota fruit protein is range is 0.6 to 0.80 and average value of protein is $0.48 \pm 0.13$. The Protein content reported in literature for sapota fruits was 0.70 and 0.67 . Ganjyal et al., 0.70 And Swaminathan is 0.70 average 0.6 [20].

\section{Fat}

The fat of Sapota fresh fruits range 0.4 to 1.25 and average fat value is $0.49 \pm 0.44$. The fat content of sapota fruits reported in literature was 1.10, 1.13 and 1.25 (Ganjyal et al., Swaminathan) [20].

\section{Carbohydrate}

The carbohydrate of sapota fresh fruits range is 14.3 to 28.31 and average carbohydrate is $19.50 \pm 3.47$. The result were in 
general agreement with the result obtained for fresh sapota fruits by Ganjyal et al., 21.40. average 28.31 [20].

\section{Fibre}

Fibre of sapota was range of 0.42 to 28.31 and average fibre is $2.50 \pm 0.92$. The result were in general agreement with the result obtained for fresh sapota fruits by Kumari et al., 2.60.

\section{Colour}

Colour L values of fresh sapota fruits are range are 57.70 to 72.10 and average $L$ value is $71.10 \pm 2.43$. Sapota a value of sapota fruits are range found 7.10 to 10.42 and average a value of sapota is $7.14 \pm 0.02$. And $b$ value of colour in sapota fruits are range comes in 37.26 to 41.91 and average value is $b$ is $40.50 \pm 0.03$ [25].

\section{Conclusion}

Moisture content of sapota found to be in the range of 73.07 $\%$ wet basis ( $280.283 \% \mathrm{db})$. And the length, width and thickness is sapota fruits was found to vary in the ranges from 44.08 to $60.19,37.00$ to 49.34 and 41.06 to $52.91 \mathrm{~mm}$, respectively, The volume of the sapota fruits range is 20 to $70 \mathrm{~cm}^{3}$ and average volume are found of sapota is $43.2 \pm 15.19 \mathrm{~cm}^{3}$.The Sphericity of sapota fruits range is found to be 0.842 to 0.990 and average value is $0.908 \pm 0.052$. The average weight of sapota fruits was $52.99 \pm 7$. the weight of sapota fruits are recorded the range 41.15 to 74.99 (g). Sapota fruits are bulk density was in the range of found 0.341 to $0.414 \mathrm{~g} / \mathrm{cc}$ and the average value of the bulk density of sapota was $0.384 \pm 0.0321 \mathrm{~g} / \mathrm{cc}$. True density of sapota fruits was in the range of found 0.952 to $2.1095 \mathrm{~g} / \mathrm{cc}$. and average true density is sapota1.323 $\pm 0.40 \mathrm{~g} / \mathrm{cc}$. The porosity is calculated by the sapota fruits was found in the range of 16.62 to 42.22 and average value of porosity is $31.492 \pm 8.45$. And some chemical properties of sapota fruits are the fresh sapota fruits the TSS range is found 17 to 23 . The Titratable acidity of sapota fruits was in the of range 0.2 to 0.25 , The $\mathrm{pH}$ of sapota fruits range was observed in the range 5.5 to 6.0 , Reducing sugar of fresh sapota fruits range was 15 to 17.3, Total sugars of fresh sapota are range between 46 to 52.2, The fresh Sapota fruit protein is range is 0.6 to 0.80 . and the fat of Sapota fresh fruits range 0.4 to 1.25 , The carbohydrate of sapota fresh fruits range is 14.3 to 28.31 and Fibre of sapota was range of 0.42 to 28.31 , Colour $L$ values of fresh sapota fruits are range are 57.70 to 72.10 and a value of sapota fruits are range found 7.10 to 10.42 .

\section{References}

1. Salleh RM, Ying TL, Mousavi L (2016) Development of fruits bar using Sapodilla (Manilkara Zapota L.). Journal of food processing and preservation: 1-7.

2. Ganjyal GM, Hanna MA, Devadattam DSK (2003) Processing of sapota (sapodilla): drying. Journal of food Science 68(2): 517-528.

3. Shirol AM, Kanamadi VC, Patil S, Thammaiah (2009) Studies on the performance of new sapota cultivars under Ghatoprabha command area. Karnataka Journal of Agriculture Science 22(5): 1056-1057.

4. Gopalan C, Ramashastri BV, Balasubramanyam SC (1985) Nutritive value of Indian foods, Ansari Nagar, New Delhi. Indian council of medical research: 1-59.

5. Kute LS, Shete MB (1995) Sapota in Handbook of fruits science and technology. In DD Salunkhe \& SS Kadam (Eds.), Marcel Dekker Inc., New York, N.K. pp. 475-477

6. Siddappa GS, Bhatia BS (1954) Identification of sugar in fruits by paper chromatography. Indian Journal of Horticulture 11(1): 19-23.

7. Shanmugavala KG, Srinivasan C (1973) Proximate composition of fruits of sapota cultivars. South Indian Horticulture 21(37): 107-108.

8. Selvaray Y, Pal DK (1984) Changes in the chemical composition and enzyme activity of two- sapodilla (Manilkara zapota) cultivars during development and ripening. Journal of Horticultural Science 59(2): 275281.

9. Mathew AG, Lakshminarayana S (1969) Polyphenols of immature sapota fruits. Photochemistry 8(2): 507-509.

10. Owolarafe OK, HO Shotonde (2004) Some physical properties of fresh Okro fruits. Journal of Food Engineering 63(3): 299-302.

11. Abbott JA (1999) Quality Measurement of Fruits and Vegetables. Postharvest Biology and Technology 15(3): 207-225.

12. Dauda AO (2014) Physico-Chemical Properties of Nigerian Typed African Star Apple Fruit. International Journal of Research in Agriculture and food sciences 2(1): 513-520.

13. Owais SJ (2007) Physical and Chemical Characteristics of Apricot fruits grown in Southern Jordan. Jordan Journal of Agricultural Sciences 3(3): 288-295.

14. Zebib H, Geremew B (2005) Studies on physical- chemical and sensory properties of Banana fruits. International Journal of scientific publication 5: 205-216.

15.Zare D, F Salmanizad (2012) Study of physical properties of olive fruits. International Journal of Biological, Agricultural, food and Biotechnological Engineering 6: 9.

16. Gadze J and S Voca (2012) Physico-chemical characteristics of main pomegranate (Punica granatum L.) cultivars grown in Dalmatia region of Croatia. Journal of Application Botany and food Quality: 202-206.

17. Jalal K, Hindisamius (2012) Study on Physical properties of Grak Fruits. International Journal of food Engineering 6: 9.

18. AOAC (1990) Moisture in dried fruits. In: Official methods of analysis. Association of Official Analytical Chemists, Washington, USA.

19. Mohsenin NN (1970) Physical properties of plant and animal materials. Gordo and Breach Press, New York, USA.

20. Ajaykumar M, Madhukar GB, Pratima NS (2012) Studies on preparation of fortified sapota-papaya fruit bar. Journal of Nutrition and Food Sciences 25: 41-44.

21. Cook R (1999) An overview of Key Food Industry Drivers: Implications for Fresh Produce Industry. Journal of Food Distribution Research 30: $1-4$.

22. McCabe WL, Smith JC, Harriot P (1986) Unit Operation of Chemical Engineering. McGraw Hill Press, New York, USA.

23. Ozturk I, Bastaban S, Ercisli S, Kalkan F (2010) Physical and chemical properties of three late ripening apple cultivars. International Agrophysics 24(4): 357-361.

24. Paul RE, Duarte $O$ (2011) Tropical Fruits. ( $\left.2^{\text {nd }} e d n\right)$, ISBN 978-1-84593672- 3, Great Britain, London, England.

25. Topuz A, Topakci M, Canakci M, Akinci I, Ozdemir F (2005) Physical and nutritional properties of four orange varieties. Journal of Food Engineering 66(4): 519-523. 
This work is licensed under Creative Commons Attribution 4.0 License DOI: 10.19080/TTSR.2018.03.555605
Your next submission with Juniper Publishers will reach you the below assets

- Quality Editorial service

- Swift Peer Review

- Reprints availability

- E-prints Service

- Manuscript Podcast for convenient understanding

- Global attainment for your research

- Manuscript accessibility in different formats

( Pdf, E-pub, Full Text, Audio)

- Unceasing customer service

Track the below URL for one-step submission https://juniperpublishers.com/online-submission.php 